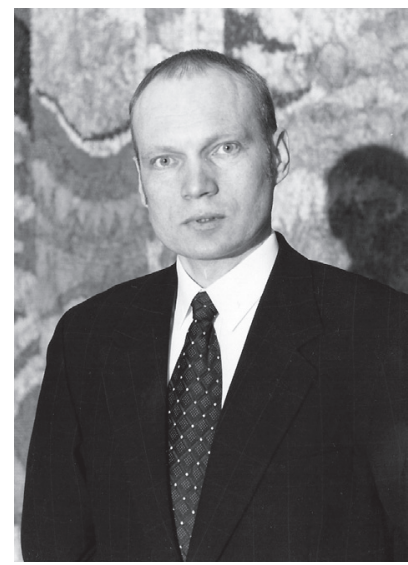

Vidmantas Mačiulskis - humanitarinių mokslų daktaras (etnologija), Klaipedos universiteto Menų akademijos Šokio katedros profesorius.

Moksliniai interesai: tautinis šokis, lietuvininkų etninė choreografija. Adresas: Kristijono Donelaičio g. 5, LT-5800 Klaipėda.

Tel. $(8 \sim 46) 398711$.

El. paštas: sk.ma@ku.lt.

Vidmantas Mačiulskis: $\mathrm{PhD}$ in Humanities, Associate Professor of Klaipeda University Academy of Arts Department of Dance. Research interests: national dance, Lietuwininkai (Prussian Lithuanians) ethnic choreography.

Address: Kristijono Donelaičio g. 5, LT-5800 Klaipèda.

Tel. $(8 \sim 46) 398711$.

El. paštas: sk.ma@ku.lt.

\title{
Vidmantas Mačiulskis
}

Klaipedos universitetas

\section{MAŽOSIOS LIETUVOS XVII A. HEIDUKA, SZALA RUTELE IR XIX-XX A. ŠOKIŲ PARALELES}

\section{Anotacija}

Straipsnyje nagrinėjami Mato Pretorijaus XVII a. užrašyti Mažosios Lietuvos šokiai Heiduka ir Szala rutele. Aptariamos ju paralelès su vèlesniais XIX-XX a. šių šokių variantais, užrašytais Mažosios Lietuvos teritorijoje - Klaipėdos krašte ir dalyje Karaliaučiaus krašto (dab. Kaliningrado sr.) bei Žemaitijoje. Tyrinėjamos šokių paskirties, formų, figūrų sąsajos ir jų kaita.

PAGRINDINIAI ŽODŽIAI: lietuvininkai, etnine choreografija, iniciacija, apeiga, šokis.

\begin{abstract}
The present article presents analysis of the dances Heiduka and Szala rutele of the inhabitants of the Lithuania Minor described by Matas Pretorijus in the $17^{\text {th }}$ century. The article discusses the parallels between the dances hereinabove with the later variants of these dances described in the territory of the Lithuania Minor - in Klaipeda region and a certain part of Königsberg area (current Kaliningrad Oblast) - and in Samogitia in the $17-20^{\text {th }}$ centuries. The interrelationship and change of the purpose, forms and figures of dances are analyzed.
\end{abstract}

KEY WORDS: Prussian Lithuanians, ethnic choreography, initiation, rites, dance.

DOI: http://dx.doi.org/10.15181/rh.v17i1.1156

Itvadas

Istorijos vingiuose laikas buvo negailestingas lietuvininkams. Pirmojo pasaulinio karo negandos, pokario sunkumai, Antrasis pasaulinis karas išblaškè senuosius lietuvininkus po visą Europą, po Sibirą. Daugelis senųjų Mažosios Lietuvos 
gyventojų po karo nebegrịžo ị gimtąsias vietas. Ištisi pamario kaimai liko tušti. I ši kraštą kèlèsi ateiviai iš kitų Lietuvos regionų. Etnologè Aušra Zabielienė, tyrinẻjusi Klaipėdos krašto folkloro ansamblių pateikiamą etnokultūrinị paveldą, pažymi, kad folkloro ansamblių dalyviai dažniausiai atvykę iš Žemaitijos ir jiems svetimas, nežinomas lietuvininkų etninis tapatumas ${ }^{1}$. Nelikus daugelio senųjų vietinių gyventojų, lietuvininkų etnochoreografinės tradicijos yra atkuriamos remiantis tik archyvuose išlikusia medžiaga ir dainynais bei pačių kūrèjų menine išmone. Matyt, tai lemia mokslinių tyrimų apie lietuvininkų etnochoreografiją stoka. Darbų, kuriuose aptariama lietuvininkų šokio tradicija, mažoka (Kazys Poškaitis $^{2}$, Dalia Urbanavičienè ${ }^{3}$, Vidmantas Mačiulskis ${ }^{4}$ ). Šiuo straipsniu tęsiami lietuvininkų etninès choreografijos tyrinejjimai, padèsiantys Lietuvos etnografiniams ir tautinio meno ansambliams tinkamai (at)kurti lietuvininkų choreografini paveldą.

Mato Pretorijaus veikalas Deliciae Prussicae oder Praussische Schaubühne (Prūsijos ìdomybès, arba Prūsijos regykla $)^{5}$ yra vienas reikšmingiausių šaltinių XVII a. Mažosios Lietuvos žmonių gyvenimui ir kultūrai pažinti. Gimęs apie 1635 m. Klaipèdoje, etniniu požiūriu mišrioje šeimoje, būsimasis istorikas patyrẻ kelių kultūrų sąveiką ir šeimoje (kalbančioje ir vokiškai, ir lietuviškai), ir to meto Prūsijos Kunigaikštystès visuomenèje. M. Pretorijus 1655-1657 m. studijavo Karaliaučiaus, o 1657-1660 m. - Rostoko universitete, ten gavo laisvųju menų ir filosofijos magistro laipsnị. Nuo 1664 m. tapo Nybudžių liuteronų bažnyčios kunigu ir dirbo ten dvidešimt metų - iki 1684 m. Nybudžiuose M. Pretorijus pradejo istoriko ir etnografo darbą, èmė rinkti medžiagą Prūsijos krašto istorijai, iki 1684 m. padarè didžiąią darbo dalị ir rašè veikalą Deliciae Prussicae oder Preussische Schaubühne (Prūsijos j̇domybès, arba Prūsijos regykla), kuriame visapusiškai aprašè Prūsijos gyvenimo realijas: istoriją, kultūrą, tautybes, kalbą, tikejjimą, liaudies papročius ir kt.

1 Aušra Zabielienè. Klaipėdos krašto etnokultūrinis paveldas šiuolaikiniuose folkloro ansambliuose. Lituanistika, t. 54, nr. 3(75). Vilnius: Mokslo akademija, 2008, 72.

2 Kazys Poškaitis. Liaudies choreografija. Vilnius: Lietuvos liaudies kultūros centras, 1992.

3 Dalia Urbanavičienè. Lietuvių apeigine etnochoreografija. Vilnius: Lietuvos muzikos akademija, 2000.

Dalia Urbanavičienè. Šokamosios ir žaidžiamosios sutartinès. Vilnius: Kronta, 2009.

Dalia Urbanavičienè. Lietuvininkų choreografijos pedsakais. Lietuvininku žodis. Parengè Norbertas Vèlius, Kazys Grigas, Zita Kelmickaitè. Kaunas: Litterae Universitatis, 1995.

4 Vidmantas Mačiulskis. Hermanno Huffzigerio sudarytas Rytų Prūsijos šokių leidinys Der Tanzkreis. Alte und neue Vokstänze aus Ostpreußen. Liaudies kultūra VI. Vilnius: Lietuvos liaudies kultūros centras, 2008.

Vidmantas Mačiulskis. XVII-XIX a. lietuvininkų šokis kaip etninės tapatybės ženklas.

Res humanitariae III. Klaipeda: Klaipèdos universiteto leidykla, 2008.

Vidmantas Mačiulskis. Lietuvininkų šokis prof. J. Lingio archyve. Res humanitariae V.

Klaipèda: Klaipėdos universiteto leidykla, 2009.

5 Prätorius M. Delicia Preussicae der Preussische Schaubühne. Berllin, 1871. 
Tyrimo objektas - M. Pretorijaus XVII a. užrašyti Mažosios Lietuvos šokiai Heiduka ir Szala rutele ir vėlesni XIX-XX a. šių šokių variantai, užrašyti Mažosios Lietuvos teritorijoje - Klaipèdos krašte ir dalyje Karaliaučiaus krašto (dab. Kaliningrado sr.) bei Žemaitijoje.

Straipsnio tikslas - išanalizuoti M. Pretorijaus XVII a. užrašytų Mažosios Lietuvos šokių Heiduka ir Szala rutele paraleles su XIX-XX a. užrašytais šių šokių variantais.

Uždaviniai: ištirti šokių paskirties, formų, figūrų, žingsnių sąsajas, aptarti jǔ kaitą.

Tyrimo metodai - analizès, retrospekcijos, rekonstrukcijos, lyginamasis, lauko tyrimo ir apibendrinimo.

\section{Škis Heiduka}

M. Pretorijaus šeštojoje „Prūsijos įdomybès, arba Prūsijos regykla“ knygoje „Senovès prūsų konsekracijos“ septintame, aštuntame, devintame ir dešimtame skyriuose aprašomos senovès prūsų apeigos ir jų detalès, kurias lietuvininkai dar XVII a. atlikdavo per vestuves, sužadètuves, krikštynas ir laidotuves ${ }^{6}$. Aštuntame knygos skyriuje prie aprašomų lietuvininkų vestuvių papročių $M$. Pretorijus mini vyrų atliekamą šoki Heiduka (Pretorijus 2006, 635) bei pateikia šokio litografini piešinị (žr. 1-2 pav.).

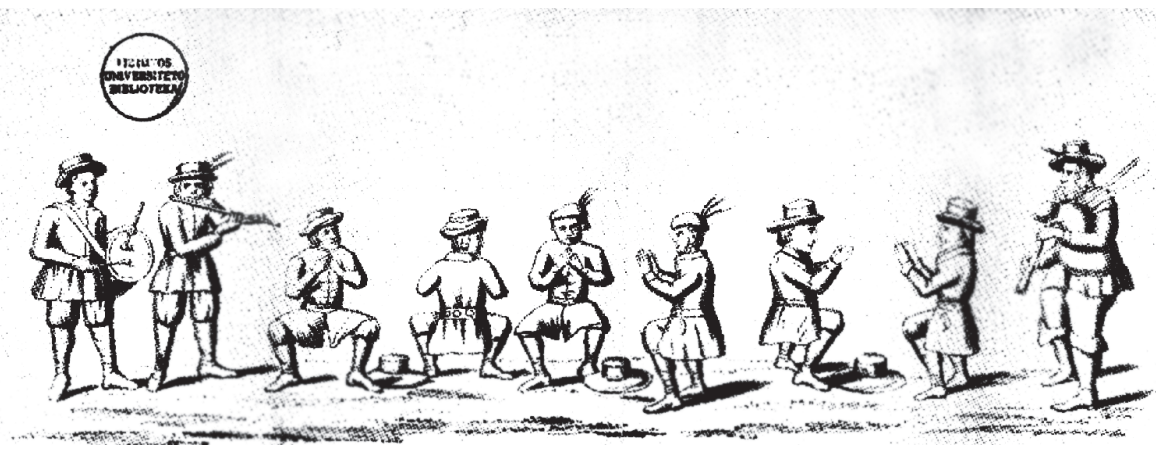

1 pav. Šokio Heiduka piešinys (Pretorijus 2006, 636)

Iš piešinio galima susidaryti pakankamai aiškų šokio vaizdą. Ji atlikdavo 6 vyrai, šokdami po du apie padètas ant žemès tris kepures. M. Pretorijui šokio būdas pasirodè ganètinai savitas, nes rašoma, kad buvo šokama savu būdu. Galima

6 Matas Pretorijus. Prūsijos ịdomybès, arba Prūsijos regykla, t. 3. Sudarytoja Ingė Lukšaitè. Parengè Milda Girdzijauskaité, Sabina Drebello, Mintautas Čiurinskas. Vilnius: Lietuvos istorijos instituto leidykla, 2006, 575-644. 
išskirti šokio formą - sustojus priešpriešiais šoko šeši vyrai, t. y. 3 poros šokejjų. Pateiktame litografiniame šokio paveiksle M. Pretorijus vaizduoja šokejjų koju padètis: šokama antrąja kojų pozicija.

Kartu pažymima: „pašokama mandagia poza“, matyt, šokyje buvo atliekami liuoksniai (pašokimai ị aukštị arba kiek ị tolị, atsispiriant ir nušokant abiem kojom $)^{7}$ ir šuoliai (pašokimai, atsispiriant viena koja ir nušokant kita) (LSŠP 1994, 54). Šokant tikriausiai vyko pasikeitimas vietomis. Be to, pavaizduota šokejju rankų delnų padètis, kuri vėliau neaptinkama kituose lietuvių šokiuose. Autoriaus paminejjimas, kad vyrai šokdavę sulenktas rankas iškèlę aukštyn, leidžia manyti, kad tai galèjęs būti apeiginis vaikinų iniciacijų ${ }^{8}$ šokis.

Pasak Balio Sruogos, lietuvių tautosakoje vaikino kepurè, merginos vainikas tolygios sąvokos. „Užkrito rasa už kepurès, už vainiko - dingo jaunos dienelès; iš čia ir ašaros, ir liūdejjimas... Einant liaudies simbolika: kepurè = vainikas; rūta = žirgas; žiedas = pentinai; darželis = klètelè $=$,stainelè“, kur mylimas žirgas esti“"9 .

Dèl vainiko, taip pat ir dèl kepurès, yra susiformavęs ištisas šeimos liaudies dainų ciklas, kuriose tie simboliai nustojo savo pirmykštės reikšmès ir pasidarè dainų objektai, pvz.:

Skrenda brolytis,

Skrenda jaunasis,

O jo kepurèle

Viršuj vandens plaukia.

Gelbèk, mergyte,

Gelbèk, jaunoji.

Jei ne mane pati,

Noris kepurèle.
Ant jūrių marių,

Ant vandenuku -

Čionai plūduriavo

- - - . - . - - - -

Gelbèk, brolyti,

Gelbèk, jaunasai,

jei ne mane pačia,

Norint vainikeli. ${ }^{10}$

Tad galima manyti, kad abiejose šiose dainose jūra reiškia žmogaus nedalią, gyvenimo pavojų, kuriame žūsta ir vaikinas, ir mergina, o maldavimas gelbèti kepurę ir vainikèlị yra maldavimas gelbèti jų garbę ir gerą vardą. Tad matome, kad kepurè vaikinui buvo ypač svarbus simbolis.

Galima daryti prielaidą, kad XVII a. M. Pretorijaus aprašytas šokis Heiduka buvo vaikinų iniciacijos ritualo dalis. Šokis, žaidimas, apeiginis veiksmas inici-

7 Lietuviu sceninio šokio pagrindai (LSŠP). Sudarè: Juozas Lingys, Juozas Gudavičius, Jūratė Čapaitè, Almutė Gražulienè. Klaipèda: Rytas, 1994, 45.

8 Iniciacija - perèjimo iš vaiko ị suaugusiųų gyvenimą arba iš vienos amžiaus grupès ị kitą ritualas. Žr. D. Urbanavičienè. Lietuvių apeigine etnochoreografija. Vilnius: Lietuvos muzikos akademija, 2000, 66.

9 Balys Sruoga. Dainu poetikos etiudai. Kaunas, 1927, 107.

10 Georg Nesselmann. Litauische Volkslieder. Berlin, 1853, 366-367. 


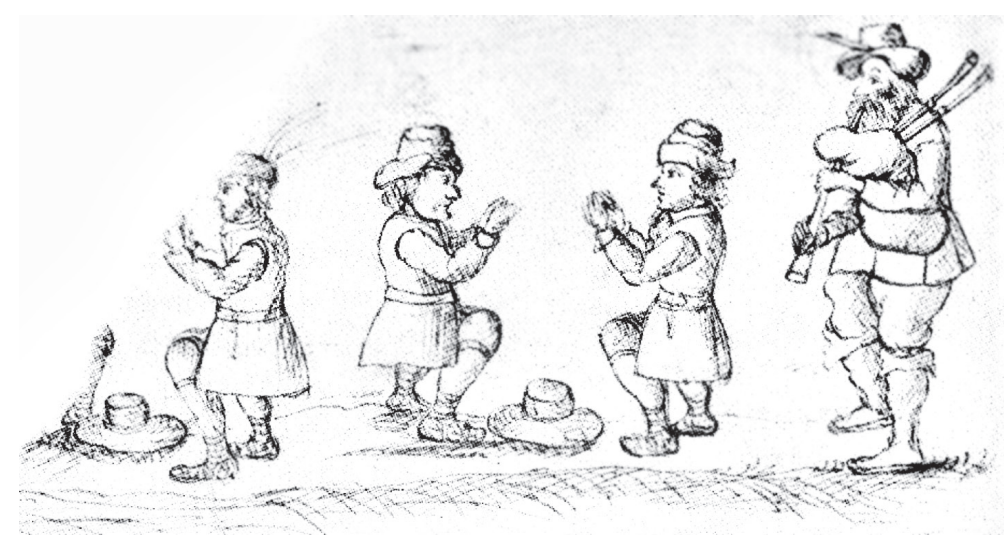

2 pav. Šokio Heiduka piešinys (Pretorijus 2006, 636)

acijų rituale neretai reikšdavo tam tikrą ceremoniją ir buvo apeigos ekvivalentas (Urbanavičienè 2000, 66). Mažèjant iniciacijų reikšmei, kai kuriose kultūrose išliko tik koks nors vienas iniciacijų ritualo momentas: pvz., neofito atskyrimas nuo bendruomenès arba jo drabužių pakeitimas ${ }^{11}$.

Galimas dalykas, kad XVII a. vaikinų šokis Heiduka buvo jų perejjimo ị vyrus iniciacijos ritualo dalis. Jis atliekamas vestuvėse. Pasak Žilvyčio Bernardo Šaknio, būtent vestuvèse atliekamos iniciacijų apeigos galejo būti skirtos ne tik merginoms, bet ir vaikinams ${ }^{12}$.

Tokio pat pavadinimo ir panašios formos XIX a. pabaigoje Mažojoje Lietuvoje (Natangoje) užrašytas Der Heiduckentanz (Haiduku šokis) ${ }^{13}$. Ji pateikè Liza Treike iš Karaliaučiaus. Šoki atlikdavo trys poros (6 atlikejjai). Jo pradžioje viena eile būdavo sustatomos trys kèdès, tokiais tarpais, kad vienas asmuo juose galètu šokti. Muzika buvo dviejų dalių, metras - 3/4. Grojant muzikos izžangai, merginos atsisėsdavo ant kẻdžių, o vaikinai sustodavo eilès gale. Grojant pirmajai šokio melodijai, vaikinai mazurpolkès ${ }^{14}$ žingsniu šokdavo grandinėlę (gyvatėlę) tarp kėdžių. Grojant antrajai šokio melodijai, išsirinkę porą šokejjai susikabindavo valsui ir šokdavo mazurpolkę ratu.

Panašios šokio formos ir figūros, tik kito pavadinimo yra 1948 m. apie Švèkšną užrašytas šokis Karūnacija (žr. 3-4 pav.):

11 Вера Еремина. Ритуал и фольклор. Ленинград, 1991, 145.

12 Žilvytis Bernardas Šaknys. Jaunimo brandos apeigos Lietuvoje. Iš: Lietuvos etnologija I. Vilnius, 1996, 166-167.

13 Hermann Huffziger. Der Tanzkreis. Alte und neue volkstümliche Tänze aus Ostpreußen I. Leipzig, 1930, 21.

14 Mazurpolke - lenkų liaudies šokis, kurio metu šokama polka. Muzikos metras 3/4 ar 3/8. XIX a. paplito daugelyje Europos šaliu kaip pramoginis šokis. Žr. Tarptautinių žodžiu žodynas (TŽŽ). Parengè V. Vaitkevičienè. Vilnius: Žodynas, 2007, 663. 


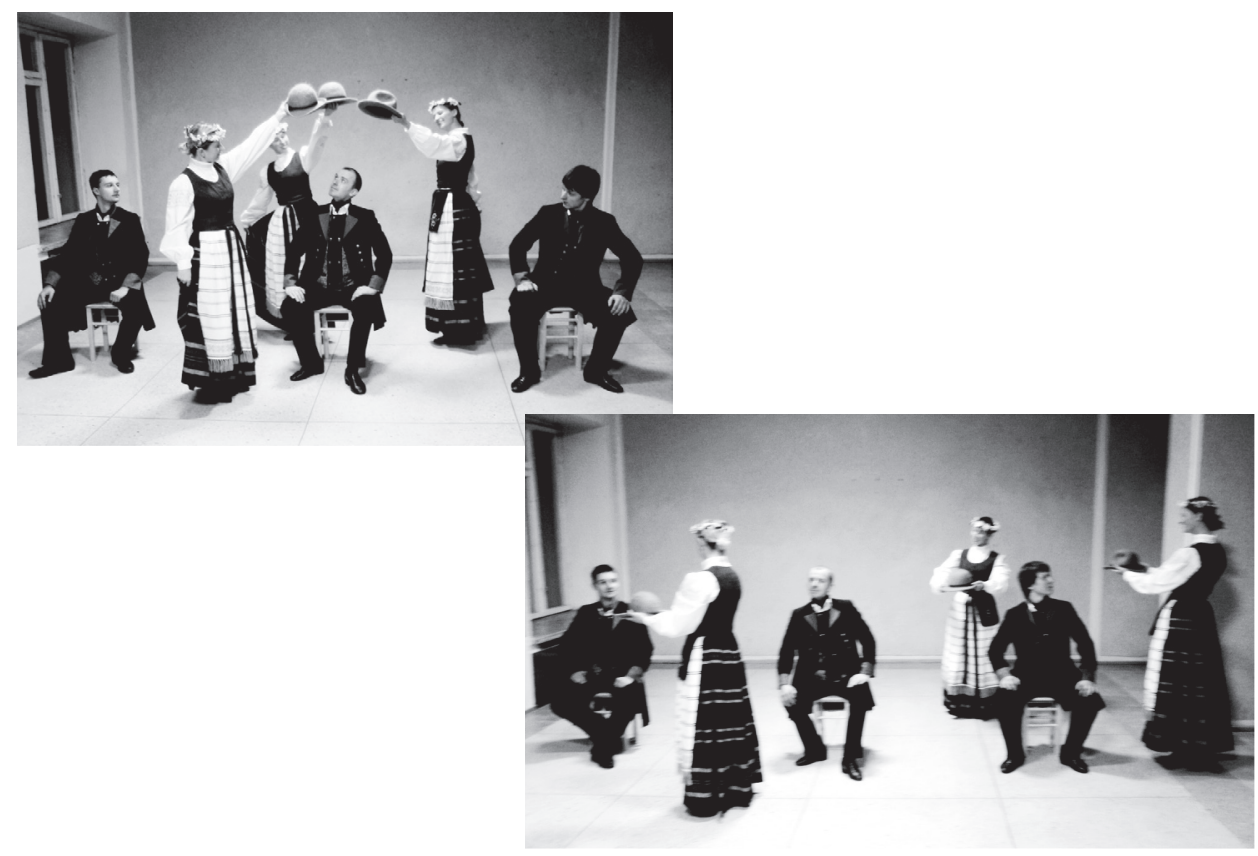

3-4 pav. Šokis Karūnacija

(rekonstruota pagal S. Girčiaus aprašą. V. Mačiulskio nuotrauka)

Šokio pradžioje aslos viduryje pastatydavo tris kèdutes. Trys šokëjai ant ju atsisèsdavo. Likusieji pradèdavo paprastuoju žingsniu eiti apie sédinčiuosius. Eidami laisvas rankas su kepurèmis laikydavo pakèle virš sèdinčiojo galvos, lyg sudarydami žvaigždutę. Taip apëjus apie kiekviena, muzika pradèdavo groti greičiau, o šokèjai pradèdavo bègti, ,vinguriuoti“ apie sèdinčiuosius. Taip šokdavo, kol atsibosdavo. Vèliau pasikeisdavo vietomis ${ }^{15}$.

Pateikėjas Stasys Girčius šokį išmokęs iš savo mamos, kuri buvo kilusi iš Klaipeddos krašto. Pasak pateikejjo, Karūnacija šokdavo vestuvių metu apie Švèkšną, Šilutę. Todèl šokis naudojamas lietuvininkų šokių tyrimams. Švèkšna yra paribyje su Mažąja Lietuva. Žmonių gyvenimas paribyje visada buvo susijęs su kultūriniais mainais ir gretimų etninių kultūrų perèmimu.

Aptarti šokiai Heiduka, Haiduku šokis ir Karūnacija panašūs ne tik pavadinimais, bet ir šokio forma - linija, tik pirmajame šokama apie padètas tris kepures, o kituose - tris kèdutes ir sėdinčius šokejjus.

Be to, šokio Karūnacija metu virš sėdinčio šokejjo galvos sudaroma žvaigždutè. Matyt, tai išlikusių iniciacijų ar vestuvių apeigų liekana, laikui bėgant praradusi savo apeiginę prasmę ir tapusi poros pasirinkimo ekvivalentu. Galima manyti,

15 KUŠK - Klaipèdos universiteto Šokio katedros folkloro archyvas - K 64-47/1. 
kad XVII a. M. Pretorijaus aprašytas vyrų šokis Heiduka laikui bėgant prarado savo apeiginę prasmę ir tris padètas ant žemès kepures pakeite trys kẻdutès. Tačiau tiek šokio forma - linija, tiek figūromis - grandinèle, šie šokiai panašūs. Be to, visus aptartus šokius atlieka šeši šokejjai arba trys poros atlikejjų.

Galima daryti prielaidą, kad XIX a. pabaigoje - XX a. viduryje gyvavę Haidu$k u$ ir Karūnacijos šokiai gali būti M. Pretorijaus paminèto šokio Heiduka vèlesni variantai, metams bėgant pasikeitus apeiginei šokio paskirčiai virtę pasilinksminimo šokiais. Vaikinų iniciacijos jaunimo bendrijoje ir vestuvèse galejo sudaryti bendrą ciklą - panašiai kaip ir merginų, tik vaikinų iniciacijų laikotarpis tarp pradinès ir baigiamosios ciklo dalies buvo ilgesnis. Anot Dalios Urbanavičienès, vestuvių apeigose aptinkami vaikinų iniciacijų fragmentai leidžia manyti, kad vedybinį vaikino amžių įteisinanti iniciacijų dalis seniau buvo labiau išplètota, tačiau vèliau sunyko arba tiesiog nebuvo pakankamai aprašyta (Urbanavičienė 2000, 80).

Šokio formos ir figūrų panašumų galima rasti tarp Rytų Prūsijoje dar XVII a. viduryje M. Pretorijaus užrašyto šokio Heiduka (Skrybèliu šokis) (Pretorijus 2006, 635), XIX a. pabaigoje apie Karaliaučių šokto Haiduku šokio (Huffziger 1930, 21), XX a. pradžioje paribyje su Mažąja Lietuva šokto šokio Karūnacija (KUŠK K 64-47/1) bei XX a. Žemaitijoje užfiksuotų šokių: Pintuvinio (KUŠK P-23), Kepurinio (KUŠK K-22), Dujos ${ }^{16}$ ir Skruzdèlès ${ }^{17}$.

Žemaitijoje šokis minimas tik XX a. viduryje: Kretingos rajone apie Salantus prieš vestuves, Pintuvių vakarą, jaunimas šokavo Pintuvinį. Šokdavo tik trys poros. Šokiui buvo reikalingos trys kèdès žemais atlošais. Muzika panaši i t polkos (KUŠK P-23).

Kambario viduryje viena eile buvo pastatomos trys kèdès. Šokdamos polka, ateidavo trys poros, apšokdavo aplink kèdes, ir vyrai merginas pasodindavo ant jų. Vèliau visi trys vyrai, susikabinę rankomis virš sèdinčios pirmosios merginos, sudarydavo žvaigždutę ir polkos ar dvigubuoju žingsniu apsukdavo ratq. Tada pereidavo prie vidurinés merginos, žvaigždutę apsukdavo virš jos ir galiausiai visa tai pakartodavo virš trečiosios merginos. Toliau, eidami vienas paskui kita, vyrai tarp sèdinčių merginu šokdami „rašydavo aštuoniukę“ (KUŠK P-23).

Panašios šokio formos šokis Skruzdèle užfiksuotas Skuodo rajone, apie Ylakius. Pateikejjo žodžiais, tai vestuvinis šokis, skirtas senoms moterims, kad būtu galima ir pašokt, ir pažiūrèt ị jas. Šiam šokiui taip pat reikalingos trys kèdès.

16 LTR - Lietuvių literatūros ir tautosakos instituto Lietuvių tautosakos rankraštynas - 1226/49.

17 Audronè Vakarinienè. Šoks broliukai šokinị. Vilnius: Lietuvos liaudies kultūros centras, 2001, 292. 
Kambario viduryje vienoje eileje pastatomos trys kèdès. Ant ju atsisèsdavo trys moterys. Kitos trys, susikabinusios dešinèmis rankomis, sudarydavo žvaigždutę virš pirmosios, véliau antrosios ir trečiosios sèdinčios moters galvos. Apsukusios žvaigždutes aplink visas tris sèdinčiqusias, moterys paleisdavo rankas ir pradèdavo „rašyti“ dviguba aštuoniukę ${ }^{18}$.

Kiek kitoks šokio variantas Duja (LTR 1226/49), užrašytas Šiluvos apylinkėse. Troboje pastatydavo tris kẻdes. Ant jų atsisėsdavo trys merginos, o kiti šokejjai, sudarę grandinèlę, vedžiodavo aplinkui. Kazys Poškaitis 1958 m. Rietavo rajone užraše šoki Kepurinis. Jị šokdavo pagyvenę žmonès. Buvo reikalinga viena kepurè, trys kèdès ir trys poros šokejjų.

Trys vyrai susèsdavo ant kèdžiu, o trys moterys, dešinemis rankomis laikydamos virš pirmojo vyro galvos pakeltą skrybèlę, paprastuoju žingsniu sukdavo žvaigždutę j dešinę. Tokiu pat būdu sukdavo žvaigždutę virš antrojo ir trečiojo vyru. Vèliau šokị kartodavo nuo pradžios, tik žvaigždutę sudarydavo vyrai. Aštuoniukę, pasak pateikëjos, galima buvo šokti polkos arba dvigubuoju žingsniu (LTR 1226/49).

K. Poškaičio užrašytame Kepurinio šokyje šokejjos sudarydamos žvaigždutę virš sẻdinčio vyro galvos laikydavo pakeltą kepurę. Tai labai panašu į A. Girčiaus Švèkšnos apylinkėse užrašytą šokį Karūnacija. Matyt, kepurès laikymas virš sėdinčio šokèjo galvos bus atėjęs iš senesnių laikų ir išlaikęs apeiginių šokių elementų.

Apžvelgus etnografinę medžiagą matyti, kad Žemaitijoje gyvavusius skirtingu pavadinimų šokius - Pintuvinis, Kepurinis, Duja ir Skruzdèle - sieja aštuoniukių „rašymas“ ir žvaigždučių sukimas. Visuose šokiuose buvo naudojamos trys kẻdės ir šokdavo tik trys poros arba trys šokejos.

Kai kur virš sėdinčio šokejjo galvos buvo laikoma kepurè. Vienur tai buvo vestuvinis šokis, kitur tik pasilinksminimo vakaronių dalis. Šokant Kepurinị ir Pintuvini būdavo pasirenkama pora.

Šokio forma (trys poros) ir figūromis (aštuoniukių „rašymas“ ir žvaigždučiu sukimas) Žemaitijoje užrašyti šokiai artimi Rytų Prūsijoje ir Mažojoje Lietuvoje šoktiems Haiduku šokiams. Kadangi panašių pavadinimų ir šokio formos Rytu Prūsijoje ir Mozūrijoje užfiksuota ir daugiau šokių Heiduka ${ }^{19}$, tikètina, kad triju porų šokiai buvo būdingi Rytų Prūsijos ir Mažosios Lietuvos regionams. Šią hipotezę patvirtina ir Lietuvos liaudies kultūros centro choreografinio folkloro archyve saugoma medžiaga, kurioje yra keletas panašios formos ir figūrų šokių, užrašytų Skuodo rajone, vadinamų Vokietuko vardais (LLKC V-120/45). Tad tikètina, kad ir pats šokis bus atkeliavęs iš Rytprūsių ir prigijęs Žemaitijoje.

18 LLKC - Lietuvos liaudies kultūros centro folkloro archyvas - K 64-47/1.

19 Maria Drabecka. Taniec ludowy. Kultūra ludowa Mazurow i Warmiakow. Jozef Burgzta. Wroclaw: Wydawnictwo, 1976, 221. 
Kartografiniu principu sudèliojus įvairiais laiko tarpsniais šoktus šokius XVII a. Heiduka (Nibūdžiai), XIX a. Haiduku šokis (Karaliaučiaus apylinkès), XX a. Karūnacija (Švèkšna), Pintuvinis (Kretinga), Kepurinis (Rietavas), Duja (Šiluva), Skruzdèle (Skuodas), Vokietukas (Skuodo rajonas) - matyti, jog ši teritorija apima seniau čia gyvenusiu skalvių, nadruvių ir kuršiu žemes. Pasak mokslininkų, kaip savitas etnokultūrinis regionas Mažoji Lietuva susiformavo iki XVI a. pradžios ir jos pagrindą sudare skalvių ir nadruvių, pietų kuršių ir vakarų sūduvių žemès ${ }^{20}$.

Lina Petrošienė, tyrinėjusi lietuvininkų etninę muziką, pažymi, kad lietuvininkų etninès muzikos lokalinius bruožus galèjo lemti Mažosios Lietuvos teritorijoje gyvenusių genčių (skalvių, nadruvių, kuršių) kultūros ${ }^{21}$.

Tad tikètina, kad dar XVII a. M. Pretorijaus užrašytas šokis Heiduka savo forma ir figūromis buvo artimas Mažojoje Lietuvoje gyvenusių skalvių, nadruvių ir kuršiuc etninėms kultūroms, kurios vẻliau buvo perimtos lietuvininkų ir vakarų žemaičių.

\section{Šokis Szala rutele}

Aprašydamas XVII a. lietuvininkų vestuves M. Pretorijus paliko ir merginuc šokio Szala rutele (Rautenkrantz „,rūtų vainikas“) litografini piešinị (žr. 5 pav.). Jame pavaizduotos lietuvininkès, šokančios apsirengusios to meto tautiniais dra-

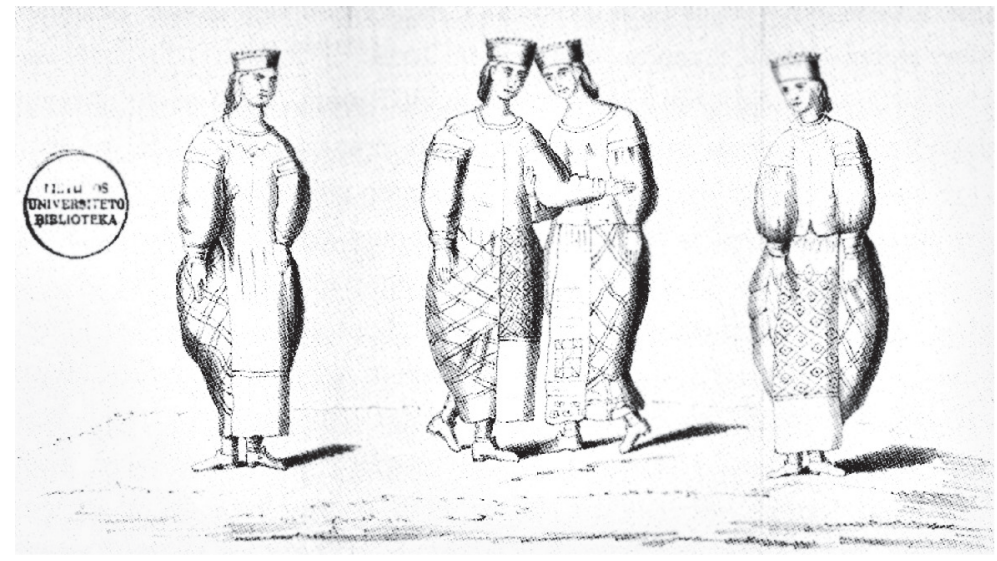

5 pav. Šokio Szala rutele piešinys

Šaltinis: (Pretorijus 2006, 639)

20 MLE II - Mažosios Lietuvos enciklopedija II. Parengè: V. Pèteraitis, Z. Zinkevičius, M. Purvinas, V. Bagdonavičius ir kt. Vilnius: Mokslo ir enciklopedijų leidybos institutas, 2003, 761.

21 Lina Petrošienè. Lietuvininku etninè muzika: tapatumo problemos. Klaipėda: Klaipėdos universitetas, 2007, 264 . 
bužiais. M. Pretorijaus pastebejjimas, kad šokis buvo palydimas daina, atliekama „savu būdu“, patvirtina savitą dainavimo ir šokio tradiciją.

Szala rutele aprašyme pažymèta keturkampio - sustojus priešpriešiais - šokio forma. K. Poškaičio nuomone, ši šokio forma, sustojus priešpriešiais (country dance), vèliau padejjo paplisti iš Vakarų atejjusiems kadriliams, nes greta formos artimumo, panašus ir šokimo būdas - daugiausia vaikščiojama paprastuoju žingsniu, o tai atitiko lietuviškas šokimo tradicijas (Poškaitis 1992, 83).

M. Pretorijus paliko ir grafinius šokio brèžinius (žr. 6 pav.), kurie to laikotarpio šokio aprašams buvo naujovè:

A

B
B

A

Sustoja ju keturios vienos priešais kitas ir šoka viena prieš kita, viena su kita apsisukdamos ir po to su bučiniu ir tūptelëjimu atsiskirdamos; ir kai abi AA šoka, abi BB stovi (Pretorijus 2006, 635).

6 pav. Šokio Szala rutele grafinis piešinys ir aprašas

Taip pat šokio apraše paminèta ir šokio figūra - pynimas: viena su kita apsisukdamos (žr. 7 pav.).

7 pav. Šokio Szala rutele piešinys (Pretorijus 2006, 638)

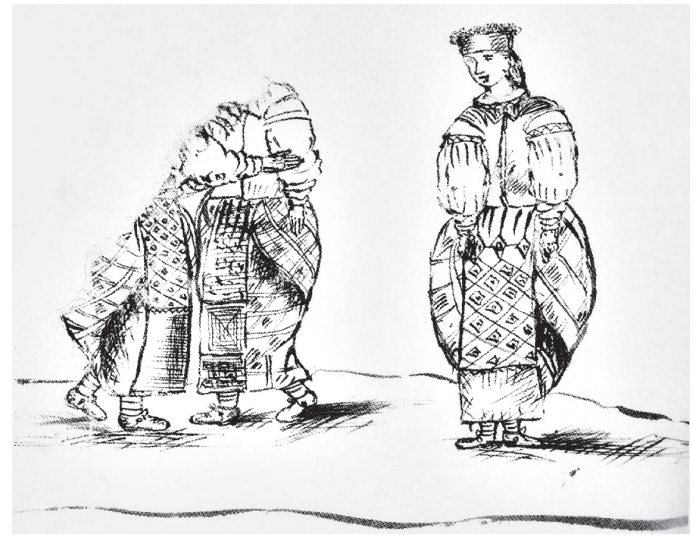

Remdamasis savitu šokio atlikimu ir jo analogija su šokamosiomis sutartinèmis, Zenonas Slaviūnas spèja, jog Szala rutele buvusi šokių sutartinè $\dot{e}^{22}$. Dèl Szala rutele sutartiniškos prigimties neabejoja ir K. Poškaitis (Poškaitis 1992, 82-83),

22 Zenonas Slaviūnas. Istorinès, humoristinès, šokių ir instrumentinès sutartinès. Vilnius: Vaga, 1959, $15-16$. 
Irena Nakiené ${ }^{23}$, šokamųjų sutartinių pẻdsakų ižžvelgia ir Daiva Račiūnaitė-Vyčinienè $^{24}$. D. Urbanavičienè naujausioje savo studijoje iš pateiktų tyrimų daro prielaidą, kad M. Pretorijaus pavaizduotas merginų šokis Szala rutele iš esmès sutampa su keturinių sutartinių šokimo būdu (Urbanavičienė 2009, 37). Tyrèjos nuomone, šios savitos liaudies kūrybos rūšies išnykimą, matyt, nulèmė paskutiniaisiais šimtmečiais ypač paspartèjusi visuomeninio, kultūrinio ir politinio gyvenimo kultūra. Tačiau nè vienas Mažosios Lietuvos etninès muzikos tyrinėtojas neranda duomenų, kad čia būtų paplitęs daugiabalsiškumas, todẻl teigti apie sutartinių gyvavimą Mažojoje Lietuvoje būtų per drąsu. Šiam klausimui reikètų atskirų studijų.

Rūtos simbolis dažnas lietuvių tautosakoje. Rūta gali simbolizuoti ir pačią mergelę, ir jos nekaltybę, bet dažniausiai - ,ji mergelès miela draugè, su kuria ir pasikalbama, ir pasitariama, joje atsispindi mergelès pergyvenimai“ (Sruoga 1927, 108).

Kitaip sakant, rūta yra objektas, kuriuo mergelè operuoja santykiuose su vaikinu. Mergelè, pasisèjusi rūtą, nusipynusi vainikèlị, jau yra pasirengusi tekèti. Tad galima manyti, kad M. Pretorijaus užrašytas vestuvinis merginų šokis Szala rutele galèjo priklausyti merginų iniciacijų ritualui, nes, kai rūta pasèta, užaugo, pražydo, galima ją nuskinti ir tekèti. Merginų iniciaciju papročiuose jau po pirmųjų mėnesinių būdavo akcentuojamas vedybų tikslas (Urbanavičienẻ 2000, 80). Ir merginų, ir vaikinų iniciacijų ritualai neapsiribojo tik vienkartinėmis apeigomis. Tai labiau atsispindi merginų iniciacijose, kurios būdavo atliekamos ir šeimoje, ir kaimynų bendrijoje, ir visos kaimo bendruomenès švenčiamose vestuvèse.

Galima rasti paralelių tarp XVII a. merginų šokio Szala rutele ir XIX a. pabaigoje - XX a. pradžioje ir viduryje Mažojoje Lietuvoje ir kitose Lietuvos vietose vestuvių metu šokto Sejjau rūtas šokio. Jame taip pat apdainuojama rūtos vegetacija, jos skynimas prilyginamas jaunų dienų netekimui. Be to, ir šokio forma sustojus priešpriešiais kvadratu - abiejų šokių identiška. Galima daryti prielaidą, kad XVII a. M. Pretorijaus užrašytas merginų šokis Szala rutele buvo lietuvininkių merginų iniciacijų ritualinis šokis, laikui bėgant praradęs savo pirminę paskirtį ir virtęs mišriu šokiu, šokamu per vestuves ir jaunimo pasilinksminimus.

Šokių Sëjau rūtas ir Noriu miego melodijas randame užfiksuotas XIX a. A. Bezzenbergerio Lietuviškuose tyrinëjimuose $e^{25}$. Šokio Sëjau rūtas melodija

23 Irena Nakienė. Sutartinių reliktai Mažojoje Lietuvoje. Tiltai, nr. 7. Klaipèda: Klaipėdos universitetas, 2001, 18-27.

24 Daiva Račiūnaitè-Vyčinienè. Dviejų pradų - vokalinio ir instrumentinio - susipynimas sutartinèje „Buvo dūda Vilniuje“. Lietuvos muzikologija I. Lithuanian musicology I. Vilnius: Lietuvos muzikos akademija, 2000, 50.

25 Adalbert Bezzenberger. Litauische Forschungen. Beitrage zur kenntniss der Sprache und des Volstumes der Litaure von Adalbert Bezzenberg. Gottingen, 1882, 127. 
užrašyta Klaipėdos rajone, o Noriu miego - Ragainès apskrityje (Bezzenberger 1882, 13).

XX a. Mažosios Lietuvos šokio Sëjau rūtas aprašą pateikia Vytautas Kaltenis 1956-1964 m. Rusnès ekspedicijos metu surinktoje medžiagoje ${ }^{26}$. Šokis buvo atliekamas dvieju porų, sustojus vienai prieš kitą. Šokant spyruokliniu žingsniu buvo dainuojama: Sëjau rožés, sëjau rūtas / Sëjau engertèrą, / Sëjau mano jaunas dienas / Taip kaip engertèrq̨. Vèliau, po suplojimų, šokèjai, sudarę rankomis žvaigždutes, sukdavo jas į vieną ir kitą pusę. Reikia pažymèti, kad čia taip pat naudojama žvaigždutės figūra, kuri anksčiau buvo aptarta šokyje Karūnacija. Galima daryti prielaidą, kad Sëjau rūtas taip pat galëjo būti merginų vestuvių apeiginis šokis, atliekamas apie sèdinčią nuotaką.

Tautosakos rankraštynuose galima aptikti vèlyvesnių Sëjau rūtq ir Noriu miego šokių aprašų, užrašytų Klaipedos krašte apie 1970-1986 m. Dažniausiai jie vadinami Noriu miego pavadinimu. Daugelis jų tiek šokio forma, tiek struktūra panašūs. Dažniausiai šokdavo dvi poros, sustojusios priešais (LLKC 34-47/4/, Šilutès r., Vilkyčiai), tačiau pasitaiko ir keturių porų šokių, atliekamų Šilutès r. Sipariu k. (KUŠKK S-17/9), rečiau sustojus ratu - Šilutės r. Pašyčiuose (LLKC N34-47/3) - užrašytas tik vienas toks šokio variantas. Dažniausiai atliekamos figūros: žvaigždutės arba keitimasis porose vietomis. Tik vienu atveju užfiksuotas sukimasis už parankių (KUŠK S-17/9). K. Poškaitis pažymi, kad šokiai Sëjau rūtq ir Noriu miego paplitę visoje Lietuvoje. Visuose šių šokių variantuose panašios figūros (žvaigždutės, keitimasis) bei žingsniai (spyruokliniai ar pakaitiniai liuoksniai $)^{27}$. Tad galima prielaida, kad anksčiau šokiai Sëjau rūtq buvo paplitę Lietuvoje merginų apeiginiai šokiai, laikui bėgant praradę pirminę paskirtị ir virtę mišriais pasilinksminimo šokiais. Be to, XVII a. pabaigoje Mažojoje Lietuvoje, skirtingai nuo kitu Lietuvos regionų, rūtą, kaip skaistumo ir nekaltybès simbolį, pradeda keisti mirta. Konfirmantė ${ }^{28}$ laikè rankoje mirtos šakelę. Vèliau ja puošè galvą. Ištekejjusios moters galvos apdangalas buvo kepurèle su mirtos vainiku ${ }^{29}$. Dar XX a. pradžioje lietuvininkų jaunoji buvo pasipuošusi mirtos vainiku ${ }^{30}$. Tad galima manyti, kad Mažojoje Lietuvoje rūtos simbolio reikšmès praradimas turéjo įtakos ir šokio Zalia rutele nykimui.

26 VKA - Vytauto Kaltenio Rusnès apylinkèse rinkta etnografinè medžiaga (saugoma Klaipėdos universiteto Menų akademijos Šokio katedroje).

27 Kazys Poškaitis. Apie liaudies choreografijos regioninị savitumą. Vilnius: Lietuvos liaudies kultūros centras, 2001, 117.

28 Konfirmacija (lot. confirmatio - sutvirtinimas) - krikšto sutvirtinimo apeigos. Mažojoje Lietuvoje laikyta, kad po konfirmacijos (ǐžegnotuvių) baigiasi vaikyste ir prasideda jaunystė. Žr. MLE II - Mažosios Lietuvos enciklopedija II. Parengè: V. Pèteraitis, Z. Zinkevičius, M. Purvinas, V. Bagdonavičius ir kt. Vilnius: Mokslo ir enciklopedijų leidybos institutas, 2003, 274.

29 Teresė Jurkuvienè. Lietuviu tautinis kostiumas. Vilnius: Baltos lankos, 2006, 101.

30 IIES - Lietuvos istorijos instituto Etnologijos skyriaus archyvas - 60/2, 60/17. 
Išvados

XVII a. M. Pretorijaus aprašyti šokiai Heiduka ir Szala rutele tikriausiai buvo vaikinų ir merginų iniciacijų šokiai, paplitę Mažojoje Lietuvoje. Laikui bėgant jie prarado pirminę paskirtį ir virto pasilinksminimo šokiais Karūnacija ir Sëjau rūtas, kurie išlaikè šokių formų, figūrų panašumus.

XVII a. šoktas Heiduka ir vėlesni šio šokio variantai: XIX a. Haiduku šokis, XX a. Karūnacija, Pintuvinis, Kepurinis, Duja, Skruzdèlè, Vokietukas - dažniausiai buvo atliekami šešių šokejjų arba trijų porų atlikèjų, tai rodo archajišką jų prigimti ir šokių struktūrų panašumą.

Tikètina, kad dar XVII a. M. Pretorijaus užrašytas šokis Heiduka savo forma ir figūromis buvo artimas Mažojoje Lietuvoje gyvenusių skalvių, nadruvių ir kuršių etninèms kultūroms, kurios vẻliau buvo perimtos lietuvininkų ir žemaičių.

XVII a. M. Pretorijaus aprašytam merginų šokiui Szala rutele ir XIX-XX a. Mažojoje Lietuvoje šoktiems Sẻjau rūtą, Noriu miego būdingos keitimosi ar pynimo figūros ir šokio forma sustojus priešpriešiais. XVII a. pabaigoje Mažojoje Lietuvoje rūtą, kaip skaistumo ir nekaltybès simbolị, pakeitusi mirta galèjo turèti įtakos ir šokio Szala rutele nykimui.

\section{Literatūra ir šaltiniai}

Bezzenberger 1882 - Adalbert Bezzenberger. Litauische Forschungen. Beitrage zur kenntniss der Sprache und des Volstumes der Litaure von Adalbert Bezzenberg. Gottingen.

Drabecka 1976 - Maria Drabecka. Taniec ludowy. Kultūra ludowa Mazurow i Warmiakow. Jozef Burgzta. Wroclaw: Wydawnictwo.

Huffziger 1930 - Hermann Huffziger. Der Tanzkreis. Alte und neue volkstümliche Tänze aus Ostpreußen I. Leipzig.

IIES - Lietuvos istorijos instituto Etnologijos skyriaus archyvas.

Jurkuvienė 2006 - Teresė Jurkuvienè. Lietuviu tautinis kostiumas. Vilnius: Baltos lankos.

KUŠK - Klaipėdos universiteto Menų akademijos Šokio katedros folkloro archyvas.

LSŠP 1994 - Lietuviu sceninio šokio pagrindai. Sudarè: Juozas Lingys, Juozas Gudavičius, Jūratė Čapaitė, Almutè Gražulienė. Klaipėda: Rytas.

LLKC - Lietuvos liaudies kultūros centro etninès choreografijos rankraštynas.

LTR - Lietuvių literatūros ir tautosakos instituto lietuvių tautosakos rankraštynas.

Mačiulskis 2008 - Vidmantas Mačiulskis. Hermanno Huffzigerio sudarytas Rytų Prūsijos šokių leidinys Der Tanzkreis. Alte und neue Vokstänze aus Ostpreußen. Liaudies kultūra VI. Vilnius: Lietuvos liaudies kultūros centras.

Mačiulskis 2008 - Vidmantas Mačiulskis. XVII-XIX a. lietuvininkų šokis kaip etninès tapatybès ženklas. Res humanitariae III. Klaipėda: Klaipėdos universiteto leidykla.

Mačiulskis 2009 - Vidmantas Mačiulskis. Lietuvininkų šokis prof. J. Lingio archyve. Res humanitariae $V$. Klaipeda: Klaipèdos universiteto leidykla.

Mažosios Lietuvos enciklopedija II (MLE II) 2003 - Mažosios Lietuvos enciklopedija, t. 2. Parenge V. Pèteraitis, Z. Zinkevičius, M. Purvinas. Vilnius: Mokslo ir enciklopedijų leidybos institutas.

Nakienė 2001 - Irena Nakienė. Sutartinių reliktai Mažojoje Lietuvoje. Tiltai, nr. 7. Klaipėda: Klaipèdos universitetas.

Nesselmann 1853 - Georg Nesselmann. Litauische Volkslieder. Berlin. 
Petrošienė 2007 - Lina Petrošienè. Lietuvininku etninė muzika: tapatumo problemos. Klaipèda: Klaipèdos universiteto leidykla.

Poškaitis 1992 - Kazys Poškaitis. Liaudies choreografija. Vilnius: Lietuvos liaudies kultūros centras.

Poškaitis 2001 - Kazys Poškaitis. Apie liaudies choreografijos regionini savituma. Vilnius: Lietuvos liaudies kultūros centras.

Prätorius 1871 - Matthaeus Prätorius. Delicia Preussicae der Preussische Schaubühne. Berlin.

Pretorijus 2006 - Matas Pretorijus. Prūsijos įdomybès, arba Prūsijos regykla, t. 3. Sudarytoja Ingė Lukšaitė. Parengè Milda Girdzijauskaitė, Sabina Drebello, Mintautas Čiurinskas. Vilnius: Lietuvos istorijos instituto leidykla.

Račiūnaitė-Vyčinienè 2000 - Daiva Račiūnaitė-Vyčinienė. Dviejų pradų - vokalinio ir instrumentinio - susipynimas sutartinèje „Buvo dūda Vilniuje“. Lietuvos muzikologija I. Lithuanian musicology I. Vilnius: Lietuvos muzikos akademija.

Sruoga 1927 - Balys Sruoga. Dainu poetikos etiudai. Kaunas.

Slaviūnas 1959 - Zenonas Slaviūnas. Istorinès, humoristinès, šokiu ir instrumentinès sutartinès. Vilnius: Vaga.

Šaknys 1996 - Žilvytis Bernardas Šaknys. Jaunimo brandos apeigos Lietuvoje. Lietuvos etnologija I. Vilnius.

Tarptautinių žodžių žodynas (TŽŽ) 2007 - Tarptautiniu žodžių žodynas. Parengè V. Vaitkevičienė. Vilnius: Žodynas.

Lietuvininkų žodis (LŽ) 1995 - Dalia Urbanavičienè. Lietuvininkų choreografijos pèdsakais. Lietuvininkų žodis. Parengè Norbertas Vèlius, Kazys Grigas, Zita Kelmickaitė. Kaunas: Litterae Universitatis.

Urbanavičienè 2000 - Dalia Urbanavičienè. Lietuviu apeigine etnochoreografija. Vilnius: Lietuvos muzikos akademija.

Urbanavičienė 2009 - Dalia Urbanavičienè. Šokamosios ir žaidžiamosios sutartinès. Vilnius: Kronta. VKA - Vytauto Kaltenio Rusnès apylinkèse rinkta etnografinè medžiaga (saugoma Klaipėdos universiteto Menų akademijos Šokio katedroje).

Zabielienė 2008 - Aušra Zabielienè. Klaipèdos krašto etnokultūrinis paveldas šiuolaikiniuose folkloro ansambliuose. Lituanistica, t. 54, nr. 3(75). Vilnius: Lietuvos mokslų akademija.

Еремина 1991 - Вера Еремина. Ритуал и фольклор. Ленинград.

\section{Vidmantas Mačiulskis}

\section{PARALLELS BETWEEN HEIDUKA, SZALA RUTELE - THE $17^{\mathrm{TH}}$ CENTURY DANCES OF LITHUANIA MINOR - AND THE 19-20 ${ }^{\mathrm{TH}}$ CENTURY DANCES}

\section{Summary}

The present article is an analysis of the dances Heiduka and Szala rutele of the inhabitants of the Lithuania Minor described by Matas Pretorijus in the $17^{\text {th }}$ century. The article discusses the parallels between the dances hereinabove with the later variants of these dances described in the territory of the Lithuania Minor - in Klaipeda region and a certain part of Königsberg area (current Kaliningrad Oblast) - and in Samogitia in the $17-20^{\text {th }}$ centuries. The interrelation and change of the purpose, forms and patterns of dances are analyzed. 
The study showed that Heiduka and Szala rutele dances described by M. Pretorijus in the $17^{\text {th }}$ century might have been boys and girls' initiation dances that were widely spread in the Lithuania Minor and that lost their primary purpose and transformed into recreational dances Karūnacija and Sëjau rūtas that retained the similarities of the dance forms and patterns.

Both Heiduka danced in the $17^{\text {th }}$ century and the later variants of this dance Haiduky šokis in the $19^{\text {th }}$ century, Karūnacija, Pintuvinis, Kepurinis, Duja, Skruzdele, Vokietuko dances in the $20^{\text {th }}$ century were performed by six dancers or three pairs of dancers, which testifies the archaic nature and the similarity of the structures of the dance. It is likely that the forms and patterns of Heiduka dance described by $M$. Pretorijus in the $17^{\text {th }}$ century were very close to the ethnic culture of the Scalovians, Nadruvians and Curonians, who lived in the Lithuania Minor, and that were later on adopted by the Prussian Lithuanians and the Samogitians.

Lining opposite and exchanging places or weaving dance forms were characteristic of the girls' dance Szala rutele described by M. Pretorijus in the $17^{\text {th }}$ century and Sëjau rūtq, Noriu miego dances popular in the Lithuania Minor in $19-20^{\text {th }}$ centuries. As rue as a symbol of chastity and virginity was replaced with myrtle at the end of the $17^{\text {th }}$ century, this could have affected the decline of Szala rutele dance. 